\title{
Replacing the nation in the age of migration: negotiating South Asian identities in Toronto
}

\author{
ISHAN ASHUTOSH
}

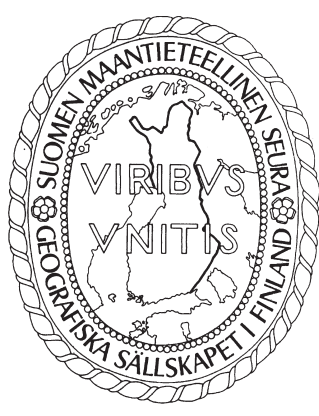

Ashutosh, Ishan. (2015). Replacing the nation in the age of migration: negotiating South Asian identities in Toronto. Fennia 193: 2, 212-226. ISSN 1798-5617.

This essay examines the role of the national in shaping the geo-political divides and connections of the South Asian diaspora in Toronto. South Asian diaspora identities are explored through two contrasting political projects that reveal the ambivalent role of the nation in producing diasporic subjectivities and their shifting borders. First, by discussing the perceptions of South Asians in Toronto, it is contended that national and religious divides are reproduced in the diaspora as a means of national belonging to the society of settlement. Diasporic geo-political divides are not merely transposed from societies of origin to settlement, but rather lie at the intersection of transnational and multicultural politics that encompass societies of origin and settlement. The reproduction of national divides in the South Asian diaspora is situated in the neighbourhoods of immigrant settlement that are positioned as the objects of multicultural efficacy. The second political project reconstitutes the national through cross-national solidarities. Through a discussion of South Asian organizations and political initiatives in Toronto and other cities in North America, this section illuminates diasporic politics predicated on new understandings of history and connection that rejuvenate and politicize multicultural politics. The argument presented finds that national boundaries are re-inscribed in the diaspora at the intersection of the multiple claims of membership. Simultaneously, experiences and interactions in the diaspora provide the grounds for transforming and questioning the limits of national belonging.

Keywords: Toronto, South Asian diaspora, multiculturalism, transnationalism, ethnography, migration

Ishan Ashutosh, Indiana University, Department of Geography, Student Building 120, 701 E. Kirkwood Ave., Bloomington, IN 47405, U.S.A. E-mail: iashutos@ indiana.edu

\section{Introduction}

This essay examines how overlapping national ideologies inform the various subjectivities of Toronto's South Asian diaspora. In many respects, the very term "South Asian" alludes to the multiple positioning of the national. The term consists of a state category that reduces national, linguistic, and religious differences (Ghosh 2013). Yet the term also signifies the historical and contemporary cross-national and anti-racist activism of people of Bangladeshi, Indian, Pakistani, and Sri Lankan origins in Canada. Their activities illustrate a diasporic politics capable of transforming the inclusions and exclusions that underwrite national membership (Ashutosh 2014). Diasporic identities are of particular significance to debates over national integration in Canada, given that twenty per cent of the country's population is foreign-born, and the country's multi-national character has been a central element of government policy and nationalist discourse since at least Prime Minister Pierre Trudeau's introduction of a multicultural policy within a bilingual framework in 1971. With a population of 1.56 million people, South Asians have been Canada's largest "visible minority group" since 2006 
with just over half of all South Asians in Canada residing in Toronto (Statistics Canada 2011).

The South Asian diaspora is composed of overlapping identities that span societies of origin and settlement. These identities are situated in the city and reveal the extent to which the global is routed through the national. As a "visible minority" group in Canada, South Asians are equated with the success and failures of multiculturalism and national integration. For societies of origin, the South Asian diaspora's transnational activity resists or enhances the post-colonial nationalisms of South Asia. For instance, the call for the homeland of Tamil Eelam championed by many Sri Lankan Tamils is violently resisted by the Sri Lankan state, while much of the Indian diaspora, once a marginal and at times threatening figure for the post-colonial state, is today reconnected to the homeland through the figure of the "global Indian" (Dickinson \& Bailey 2007; Varadarajan 2010). Toronto is today a central node in this dispersed and intricate diaspora that spans over one hundred countries (Maharaj 2003). Moreover, Toronto's South Asians encompass the various typologies of diaspora that include refugees, labour, and trade (Cohen 1997). The complexities that constitute the South Asian diaspora in Toronto, therefore, enable an interrogation of the fraught status of the nation in its everyday manifestations in the city.

The intersection of multiple national ideologies that shape the politics of the South Asian diaspora in Toronto prompt the need for an analysis attuned to the processes of cohesion and division produced by the multiple intersections of nationalism. I argue that the national contains a dual role in shaping the politics of belonging of the South Asian diaspora. On the one hand, the national reinforces geopolitical divides when nationalism is directed towards incorporation in the host society. On the other, the national is remade through South Asian cross-national solidarities in the diaspora. The focus on the South Asian diaspora more broadly exposes the moments of harmonious as well as dissonant articulations of belonging to multiple communities that frame diasporic identities and political projects.

Following Baumann's (1996) deconstruction of the perceived isomorphism between community and culture, my fieldwork focused on the overlapping claims of belonging and affiliations that stretched across the bounded notions of community. Rather than confining my research to the study of a particular national or regional group that would advance a hermetically sealed conception of culture, I have placed difference at the centre of my study. The narratives that frame this article represent a subset of a total of 55 in-depth, individual, and focus group interviews conducted in Toronto from 2007 to 2009 that focused on the complexities of diasporic identity in the city. Participants were affiliated with multiple nations including India, Sri Lanka, Tamil Eelam, Pakistan, Bangladesh, Nepal, Afghanistan, as well as "twice migrants" (Bhachu 1985) and the descendants of indentured and kangani labourers that have made their way to Canada from other sites in the South Asian diaspora. As I discovered during fieldwork, more significant than locating national or regional primary identities was to trace the various transnational routes and cross-national affiliations engendered through migrancy. This strategy allows for both the uniqueness and shared patterns of migration experiences to be highlighted. I also sought to examine the multigenerational aspect of South Asian diasporic identity formation by interviewing recent migrants, those that migrated decades ago with the liberalization of Canada's immigration policies in the mid-1960s, to the 1.5 generation and those born in Canada.

Respondents active in the representation of diaspora, such as settlement workers, activists, students, artists, were identified through my participant-observation in a number of South Asian events in the city that included multicultural celebrations, protests, town hall meetings, plays, and concerts. From there, I relied on snowball sampling for additional contacts. Equally important, however, were the participants that came to centrally shape my research through the prosaic encounters in the city that yielded brief conversations and follow up interviews. The serendipitous encounters and everyday experiences made possible by long-term ethnographic fieldwork enabled me to move beyond stakeholder interviews and to place the diversity and difference of Toronto's South Asian communities at the centre of my research.

The insistence on the diversity of respondents was by design, for the questioning of the nation is best achieved by looking beyond the categories that are purported to represent and contain the practices and agency of people. Although this essay analyses the ambivalence of multiple nations in shaping diasporic experiences, it disrupts the embedded epistemological framework of "methodological nationalism" in the social sciences (Wimmer \& Schiller 2002) that reify the national 
by viewing it as a priori and natural container for society. So long as the nation is assessed as a cohesive entity that envelops all social phenomena, scholars are bound to write nationalistic narratives, a point made abundantly clear in the title of Prasenjit Duara's (1995) Rescuing history from the nation. Methodological nationalism has occluded from analysis both an adequate explanation for the reproduction of nationalism and the new affiliations that have emerged in diaspora.

In the sections that follow, I investigate the nexus and disarticulations between the nation, state, and migration in the formation of the identities, borders, and solidarities of the South Asian diaspora. I begin by engaging with how the concept of the nation has been scrutinized in scholarship on transnational migration and diaspora. I then turn to the ways in which national inclusions/exclusions are created in the South Asian diaspora through discourses of integration that are informed by a transnational conception of belonging. The final section engages with political actions in Toronto and New York City to illuminate a progressive and inclusive form of cross-national solidarities that, in turn, remake the nation across distinct national contexts.

\section{Diasporic gatherings and the national imaginary}

The duality of the nation-migration dialectic most expressly reveals Tom Nairn's (1975) characterization of the national as "janus faced". From one perspective, nationalism is filled with the potential to be "a morally and politically positive force" (Nairn 1975: 5) as evinced by anti-colonial nationalisms and contemporary social movements. As a progressive force, appeals to the national fight against the confines of the existing limits of membership as witnessed in the 2006 immigration reform protests in the United States (Butler \& Spivak 2007). From the other perspective, the nation divides, excludes, and kills with a ferocity that led Benedict Anderson (1991) to conjure death as the more likely realization of the nation. Given that diaspora politics embody this dual character of the nation, our task remains on the very terrain laid out by Nairn that demands a confrontation with both aspects of nationalism. Since the national has not succumbed to globalization and transnational connectivity as provocatively claimed in the final decade of the twentieth cen- tury, we now must place at the centre of our analysis the intersection of multiple nationalisms and the competing pressures of integration that span multiple nation-states.

The frequent pairing of the terms diaspora and transnationalism stems from scholarship that critically examined the limits of the nation and the emergence of new forms of political, social, and economic connectivity (Rouse 1991; Gilroy 1993; Appadurai 1996; Sassen 1996). Membership, belonging, and citizenship were extended through supranational entities (Soysal 1994) and in the context of post-colonial nation-states as the regimes of differentiated rights (Ong 1999). Nevertheless, there is a tacit tension between diaspora as a formation through spatial dispersal outside the homeland and transnationalism as a new unity and connection between societies of origin and settlement (Tololyan 1991; Clifford 1994). Unlike transnationalism in which the migrant is reincorporated into the nation, the multi-dimensional relation between the nation and diaspora includes the desire and impossibility of return, projects and actions towards transforming the homeland to a nation-state, and the reproduction of the homeland outside its origins. The diasporic reimagining of the nation has been well captured by Salman Rushdie's (1991) argument that the diasporean desire to reclaim is bound to transform national fictions and myths. Rushdie's emphasis on the activity and agency in reimagining the politics of belonging instigated Homi Bhabha (1994: 170) to write "it is to the city that the migrants, the minorities, the diasporic come to change the history of the nation". This essay places such sentiments under critical scrutiny by examining the representation of migrants and articulations of belonging by South Asian migrants in the city, the stage upon which for Bhabha (1994: 170) the "emergent identifications and new social movements of the people are played out". Across Toronto's neighborhoods, in the spectacular and banal experiences of migrants, the national is reproduced, contested, and remade.

In the very act of movement beyond the territory of the nation-state, international migration exposes the limits of national imaginaries, and entails a reconstitution and reworking of identities (WaltonRoberts \& Pratt 2005). Yet, desires for return and demands for incorporation that encompass both sending and receiving societies place migrants as objects central to the delineation of the contours of the nation. In the context of receiving society, the South Asian diaspora serve as objects for narratives 
of the just, equal, and inclusive nation. For sending societies, diasporic long-distance nationalisms that operate beyond national territory are evaluated as both an incorporative strategy that span sending and receiving societies (Schiller \& Fouron 2001) or as a "politics without responsibility or accountability" (Anderson 1992: 11). Diasporic nationalisms challenge the post-colonial state's exclusions, while eliciting a cohesive diasporic identity and form of belonging, as with Sri Lankan Tamils (Fuglerud 1999). In other cases, long-distance nationalism acts in collusion with the post-colonial state, as seen in the Indian government's establishment of new citizenship regimes and institutions aimed at reincorporating the elite segments of its diaspora (Varadarajan 2010).

Despite the rise of diasporean and transnational discourses that illuminated the multi-stranded economic, political, and social connections operating across national territories, the national continued to shape notions of belonging through its de-territorialization beyond state territory, and reterritorialization in the diasporic context (Basch et al. 1994). The relation between the nation and migration has been characterized as 'ambiguous' (Van der Veer 1995) and 'ambivalent,' which led to the examinations of new hybrid social identities and national re-imaginings. Paul Gilroy's (1993: 2) provocations to imagine beyond the nation repositions hermetically sealed understanding of community with the "more difficult option" of the transverse dynamics of community and identity that, akin to Bhabha (1994), lend themselves to "creolization, metissage, mestizaje, and hybridity". Yet hybridity as reflective of diasporic identity (Bhabha 1994) is all too often removed from the everyday realities and regimenting forces of the nation-state and capital, which, as we will see in the following section, suggests that diaspora is not a ready source of progressive politics (Mitchell 1997). Moreover, hybridity potentially elides the ways that diaspora identity coheres with consumerist multiculturalism in which ethnicity is promoted as a tradable commodity (Walton-Roberts 2011). Claire Dwyer (2002) makes an important contribution by providing a situated and grounded analysis of the hybrid identities of British Muslim women who reconstruct the contours of the national by refusing to ' $\mathrm{fix}$ ' their identities in place. On the other hand, Sean Carter (2005) has examined the contexts in which diaspora reproduces the essentialized notions of community along ethnic and national lines.
These competing views on the national in relation to migration and diaspora reveal a number of salient features of the fraught relations between the nation, state, and migration. At its most fundamental, extant scholarship has shown that the national form and constructions of community are activated through multiple movements, be it across spaces, domains, state inclusions/exclusions, and the subject/object positions of national narratives. To put it another way, the national emerges through various mobilities that enable an analysis of the multiple and conflicted spaces and scales of nationalism. The following sections provide a situated analysis of the tension of diaspora between the reproduction of the national and the moments of cross-national solidarities that reconfigure the national. In the next section, such understandings of multiple identities are formulated through appeals to culture and the state that rest on the violent exclusion of others that shape one virulent aspect of the contemporary nation in relation to migration.

\section{Bordering the national in urban space}

This section is framed around the spatialization of South Asian national divides that are reconstituted in the diaspora through the intersection of multicultural and transnational politics. Canadian nationalism in the form of multiculturalism establishes the hierarchies of incorporation that perpetuate the antagonisms not only between racialized immigrants and settler descendent Canadians, but also amongst Toronto's South Asians. The re-bordering of the nation in the South Asian diaspora is not merely the outcome of post-colonial nationalisms that have traveled with diaspora. Rather, they point to the intersection of multiple nationalisms that enable elite migrants and diasporic subjects to affirm their incorporation and belonging to Canada. Although it has been noted that multiculturalism as a promotion of integration can generate antagonisms and suspicion due to competition over government funds (Buchignani 1980), in the banal reproduction of geopolitical divides the state and the discrimination of the host society are frequently absolved. The findings in this essay parallel Sarah Mahler's (1995: 3) research on Salvadorian migrants in Long Island who resent one another while "exonerating the greater society" as an outcome of the imperatives of incorporation.

At times, immigrant integration relies on the enactment of what Bonnie Honig (2001: 96) has 
called, the "supercitizen immigrant". This typology of the immigrant refers to the ways in which migrants embody the national through the promotion of the ethical values associated with the nation, particularly Lockean liberalism and a protestant work ethic that reinvigorates a consensual democracy. The immigrant as supercitizen has been a characteristic discursive component in South Asian representation in the United States and Canada since the mid-1960s. The success of this stereotype casts Asians as model minorities to be used against other racialized groups (Prashad 2000; Thobani 2007). In a 1992 article proclaiming Toronto's cosmopolitanism, journalist Haroon Siddiqui extoled this super-citizen vision of South Asians in Canada.

"South Asians believe that education is the key to success. It is an ethos that lives in just about every home. At night, when most other Toronto kids are playing the yard, these kids are sitting at the kitchen table doing their math or practicing on the piano. They do this because they are not spoiled. They have a value system that puts great emphasis on the pursuit of knowledge and of excellence". (Toronto Star 1992)

As will be discussed below, there are contradictory elements embedded within such model minority discourses, particularly in diasporic forms of belonging that Brian Keith Axel (2001) has perceptively shown shift between a national threat and opportunity.

Multicultural national belonging is predicated on claims for recognition and representation made by different groups in which, in theory, multiple national affiliations can overlap. Indeed, philosopher Charles Taylor (1994: 63) argued that multiculturalism is the inevitable future of the national as societies become increasingly 'porous' and inhabited by members who "live the life of diaspora, whose center is elsewhere". Will Kymlicka (1995), however, suggested that multiculturalism can be used as an integrative ethic and distinguished the claims of national minorities, such as the Quebecois, and those of immigrant groups. While the claims of the former may lead to calls for a parallel society, the latter wish to retain their "ethnic particularity" in voluntary organizations and in their family lives. Immigrant demands for recognition, therefore, do not run counter to national citizenship and indeed, act as the basis for inclusion. But how do the calls for recognition as the basis for inclusion elicit new rigidities along national lines that are more pronounced and enforced in the di- aspora rather than 'elsewhere'? In the daily lives of South Asian diasporic subjects, the national becomes the critical dividing line amongst South Asians in Toronto and generates a new animus in which some immigrants are convivially placed in relation to the nation at the expense of others. Multiple national allegiances and how they can be used as symbolic capital towards integration become the basis for differentiating between the socalled 'good' and 'bad' immigrants.

State border crossings symbolize both the traditional borders of the nation-state and the other scales at which borders operate, generating North America's version of what Etienne Balibar (2004: $1)$, writing in the context of the European Union, has described as new borders, dispersed "a little everywhere". For an on duty Canadian Border Service Agent at Lewiston, New York and Queenston, Ontario, Toronto's ethno-cultural mosaic as enshrined in the city's official motto "Diversity: Our Strength" was composed instead of the rescaling of national divides to urban space. While I was being questioned about my research during one of my many crossings while conducting fieldwork, the border official listed a number of immigrant groups living in Toronto: "the Chinese, Italians, Pakistanis, Indians, Portuguese, and Somalis". In a foreboding tone, the guard then ended his assessment of Toronto's borders with, "it's like Beirut!". This view renders the Greater Toronto Area (GTA) as composed of antagonistic tribalisms clearly demarcated in city space. The guard's view of the GTA as the locus of unknown threats emanating from immigrant neighborhoods recalls the tropes of balkanization in which suspicion, violence, and segregation are presented as the likely future of the nation (Ellis and Wright 1998). While Canada is often celebrated for what Cole Harris (2001) has called postmodern patriotism in which Canadian nationalism is predicated on difference between at least the English, French and First Nations people, it has also been shown that this discourse of Canada's lack of nationness in fact occludes domination and oppression through multiculturalism (Teelucksingh 2006). Positioning the suburbs as antagonistic spaces that portend the city's future have also constituted a key strategy in the city's electoral politics that depict Toronto's immigrant neighborhoods as multicultural testing grounds, as spaces that contain the objects to be incorporated. The city is at once an exceptional and an exemplary site in relation to the nation. Toronto is distinct in terms of its racial diversity and foreign-born population, but 
also the city is the exemplary site for Canadian nationalism in the form of multiculturalism.

In the narratives below, the nation serves as a central form of belonging, but also creates divides in the form of inter- and intra-group hostilities amongst South Asians. Diasporic subjects that are able to convert both symbolic and financial capital in Canada use multiple national allegiances to exclude South Asians in the name of their own incorporation in Canada. As a result, national distinctions amongst South Asians in Toronto are the outcome of the forces and desire for Canadian integration as much as a desire to cling to the increasingly distant homeland.

For the first few months after migrating to Toronto in the summer of 2000, Viresh felt that "there was something very strange about this place". On a casual late-morning walk down Gerrard Street later that fall he was reminded of the "old smells and organized chaos of India". At that moment, Viresh's settlement in Toronto was transformed to a feeling of belonging. "It struck me that fine morning when I saw Toronto as an Indian city with lots of foreigners, non-Indians. I had lived in the U.S. for six years, but in Toronto I never felt homesick". Toronto's familiarity owed itself more to Gerrard Street, whose few blocks of Gerrard "India Bazaar" have since given way to expansive South Asian businesses in the suburbs. Viresh's previous migrations before moving to Toronto, to London and then Dearborn, Michigan, were accompanied by a search for home, but in Toronto, Viresh claims, he has found home, in no small part because of the way in which the familiar and banal signs of the nation were reproduced.

Viresh gestured at a real estate advertisement with South Asian agents that monopolize Mississauga, Brampton and Scarborough. For elite Indian immigrants it is no longer about location, but as Viresh explains "is now about size. People are settling further and further away from the city", beyond Peel and to the Halton Region in the West and Pickering in the East. These migration trends reflect what Robert Murdie (2008: 9) has described as an overall pattern of immigrant settlement that has moved from the city's downtown to the suburbs, encompassing both lower income immigrant newcomers and Indian and Chinese migrants who "generally can afford homeownership in Toronto's newer suburbs". Immigrant settlements in Toronto's suburbs have transformed these once hinterlands of Toronto to what Mohammad Qadeer (2003: 11) has characterized as Toronto's eth- noburbs, spawned by immigration policies and "tied together by bonds of national origin, culture, language, and religion".

Within the municipality of Toronto, the neighborhoods of South Asian settlement lie on the fringes of the downtown core in the post-World War II suburbs while the edge cities Brampton, Mississauga, and Markham are home to the majority of the GTA's South Asian population (Hiebert 2005; Siemiatycki 2012). The longitudinal studies of ethnic enclaves in metropolitan Toronto have found South Asian ethnic enclave concentrations primarily in the eastern neighborhood of Scarborough and in the west that today link previously isolated enclaves from Rexdale to Brampton (Qadeer et al. 2010). Among those born in South Asia, those born in India constitute over fifty percent of all South Asians in Toronto, followed by twenty percent for those born in Pakistan and Sri Lanka, with five percent born in Bangladesh (Statistics Canada 2011). Hiebert (2005) finds that in the three metropolitan areas of Montreal, Toronto, and Vancouver, South Asians display high levels of residential concentration compared to the average concentration patterns for visible minority groups. According to Myles and Hou (2004), spatial concentration may only be temporary, as South Asians follow models of spatial assimilation in which they initially move into an immigrant enclave and then move out of those neighborhoods as they socially and economically integrate.

Although most South Asians reside in the GTA's middle-class suburbs, Eric Fong (2006: 63) notes that they tend to live in the economically deprived areas within these sites. Across these locales, South Asian settlement is differentiated along the intersections of nation, language, and religion. The all too popular mapping of the city's 'ethnoburbs' (Li 2009) from Brampton's 'Singhdale' (Springdale) to Scarborough as 'Scarlanka' name the social difference and distance of South Asian neighborhoods from Canadian norms.

Immigrant neighborhoods are represented as the litmus for national integration and constitute the multicultural version of what Timothy Mitchell (1988: 13) has described as "the world as exhibition" in which the world is "conceived and grasped as though it were an exhibition". To treat the world as exhibition means that social difference is reduced into an objectified spectacle. Contemporary cities are frequently depicted through their containing the world within its borders and are, therefore, reflective of the world as exhibition. 
From this perspective, the city is not depicted as the site of new collectivities that challenge the exclusions of the nation. Rather the city is carved into neighborhoods and communities along national lines that are in turn hierarchically placed in relation to national incorporations. Writing in the aftermath of the 1992 Yonge Street riot, Bhausaheb Ubale, the first Race Relations Commissioner of Ontario and author of a 1977 report that documented racism against South Asians in Toronto, decried precisely this exoticism of multiculturalism in practice. Ubale (1992: 220) lamented that "multiculturalism has further divided ethnocultural communities from the mainstream as well as from each other". Canadian nationalism, while often assessed as inclusive of difference (Harris 2001), insists on the displays of tolerance that objectify immigrants and minorities as potential challenges. In conflicts over urban space, from the "monster house" controversy in Vancouver (Ley 2010) to suburban Toronto's "Asian theme malls" (Preston \& Lo 2000), immigrants and the spaces where they reside are discursively constructed as foreign objects that constitute a threat to the norms of Canadian nationalism.

In Toronto, national differences are spatialized through representations of neighborhoods of South Asian settlement in a pattern akin to Kay Anderson's (1995) influential analysis of Vancouver's Chinatown. Anderson argued that Chinatown existed as a spatial form of orientalism based on an irreconcilably different and inferior Chineseness and a civilized English Canadian national identity. The media coverage of South Asians in Toronto has repeatedly depicted migrants as trapped by tradition and whose transnational ties to the homeland imperil national cohesion. These threats emerge from the suburbs that threaten the metropolitan center. John Barber and Tenille Bonoguore of the Globe and Mail encapsulated this view of the migrant as an object for integration in a 2007 op-ed:

"As the 2006 census data showed this week, Toronto is a multitude of mini-states where the word 'minority' will one day have no meaning. As the suburbs of Paris blaze and Londonistan spreads fear across the globe, will Toronto start seeing a budding terrorist threat in every immigrant?... No, our centre of tolerance will hold". (Barber \& Bonoguore 2007: M1)

This statement advances the notions of Canadian tolerance as being a binding force that brings people together, indeed, even transforming the supposed "budding terrorist threat". Other examples from popular media execrate South Asians as threats to the nation. The 2007 murder of Mississauga teenager Aqsa Parvez was transformed into debates over "honour killings" and the failures of multicultural integration (Haque 2010). The references to honor killings that emerged in the wake of Parvez's murder in particular resuscitated debates over using Sharia for family arbitration disputes (Razack 2007), and the 2006 arrest of the "Toronto $18^{\prime \prime}$, in which the dominant media led the outcry over the perceived radicalization of Muslims in Canada (Miller \& Sack 2010). Another representation that portrays South Asians for their multiple allegiances has been on the support and presence of the Liberation Tigers of Tamil Eelam in Toronto (Human Rights Watch 2006). In the range of these examples of what becomes clear is that South Asians are frequently depicted and tested through the notions of loyalty and Canadian norms with reference to the projections of social disintegration and national fragmentation that position the immigrant against the nation (Ellis \& Wright 1998).

\section{National incorporations and divides}

In many interviews with South Asians in Toronto, multiculturalism would often be positively evaluated for providing a sense of belonging and in reference to the ethno-cultural diversity of Toronto. Yet elite South Asians frequently saw both immigration and multicultural policies in terms of the fracturing of society and undermining the authority of the state in what has been described as the "multicultural backlash" (Joppke 2004; Vertovec \& Wessendorf 2010). In the desire to distinguish themselves from immigrants who have been depicted for their inability to integrate as discussed in the previous section, the new divides of nation and religion intersected with class to produce new antagonisms amongst Toronto's South Asians.

Popular nationalistic discourses shape the contours of belonging that reveal the ways in which the nation integrates and divides people in everyday life (Edensor 2002). Swati, an engineer who lives and works in a western suburb of Toronto argued that her Indian heritage enabled her to belong to Canada. After her parents migrated from Gujarat in 1974, Swati grew up in Oakville, Ontario and extoled the benefits of multiculturalism through references to a particular kind of diversity 
associated with the rise of Mandirs in the GTA suburbs, the one closest to her own home also the site where her 10-year-old son had enrolled in Gujarati classes. This transformation of urban space provides a sense of belonging for Swati and her family that is simultaneously Indian and Canadian. Echoing popular discourse, however, Swati feels that multiculturalism now threatens to undermine the national community by a naïve promotion of heritage that in fact produces division. Swati refers to the adjacent former municipality of Scarborough as a space that has led to ghettos that, she stressed, are "far worse than in the United States". Despite the number of studies have shown that levels of segregation in Canada are lower than those in the United States (Ley \& Smith 1997; White et al. 2003), Swati was hardly alone in making this statement. Such positions reflect the intersection of nation, religion, and class that divide in the South Asians as they seek to distinguish themselves in order to incorporate and embody the ideals of the multicultural nation.

Particularly in the suburbs of Toronto, elite members of the Indian diaspora would invoke discourses of Islamophobia that shape contemporary Canadian and American nationalisms. Statements that ranged from the fears of growing radicalization or "home grown" terrorism, however, were informed by nationalistic discourses that also operate in India and therefore, reveal a correspondence of otherwise autochthonous nationalisms that encompassed multiple nation-states and with it, multiple sites of belonging predicated on exclusions (Grewal 2005). National divides, and the accompanying categories of race, religion, and language, are not merely transplanted from societies of origin and settlement, but are utilized in order to make claims towards incorporation. The national, to put it another way, mediates how transnational affiliations are translated into multicultural incorporations.

A settlement worker living and working in Brampton, who grew up in Amritsar and migrated to Toronto from Dubai echoed a remark by Canadian Prime Minister Mackenzie King from over sixty years earlier that was used to exclude Indian migrations, in which immigration to Canada should not alter the national 'character'. Such sentiments need to be placed within the context of the termination of federal government funding for many immigrant settlement services in the GTA, prompting the closure of the South Asian Women's Centre in 2011. The burden of belonging is in the hands of the migrant and should not guide state policies and programs, she felt. In such statements about multiculturalism, immigrant success depends on where they place themselves vis-à-vis other immigrants. The settlement worker's remarks resonate with Sharmila Rudrappa's (2004) findings on Chicago's Indo-American Center, a settlement agency which promotes immigrant incorporation that reinforces divides between immigrants and Americans. Moreover, as Rudrappa claims, if "ethnic roots allow us to become American" (Rudrappa 2004: 146), the critiques of ethnic concentration and difference aid in the integration of select 'others' into the norms of Canadian society (Thobani 2007). Incorporation and national belonging is performed through the repetition of claims that express not only adherence to multiculturalism, but rather, a concern for the future of the national community.

Gopal grew up in Toronto and supplies audio and video equipment for Indian events. Similar to Swati's assessment of immigrants and the imperatives of the state, Gopal argues that immigrant segregation occurs throughout the city and in particular in the city's inner and outer suburbs that are symbols of ethno-cultural diversity:

"I am not a big proponent of multiculturalism anymore... Because it fosters an exclusive mentality. In trying to preserve different systems, we are inevitably fostering segregated communities. Some of these Indian centers, in parts of Brampton, people don't speak English. I am not talking about the elderly, I am talking about the young! That is unacceptable. We are not contributing to the country as a whole when we do that. At the same time, we demand more resources and rights to protect these cultures. It doesn't make any sense. You are coming into a new country; you are supposed to integrate into the system". (personal interview with author)

Gopal evaluates multiculturalism as a practice of preservation and not, as Kymlicka (1995) argued, as a means to integration.

The immigrant second generation is made to represent the future of multiculturalism and the anxieties of fading connections to the diasporic elsewhere. As the baseball fields in Toronto's parks are repurposed as cricket pitches, the immigrant second generation are evaluated in terms of what one respondent who migrated from Punjab as a child sarcastically called "Molson Canadian" norms of national identity. Like the commercials that depict a hockey-loving, beer-guzzling white Canadian, these norms of national identity fix the 
nation-space of Canada to a settler society and constitute the grounds of participation and belonging. In a 2007 Globe and Mail article, Marina Jimenez placed the suburbs and the immigrant second generation through the prism of Angloconformity.

"Multiculturalism isn't working that well for visible minorities. [. . .] They are less likely to identify as 'Canadian' and report more incidents of discrimination. Lovedeep Padda, who works with his father in the Indian Punjabi Bazaar at Brampton's Plaza McLaughlin Village, says he never experienced discrimination for the simple reason that he has grown up surrounded almost exclusively by other Sikh Canadians. The Canadianborn son of Sikh immigrants, he has also never been to summer camp, taken in a Blue Jays or Maple Leafs game or a rock concert". (Jimenez 2007: A8).

The hegemonic constructions of integration are predicated on the ability of immigrants and their children to "converge to the average performance of native-born Canadians and their normative and behavioural standards" (Li 2003: 315). As Amita Handa (2003) has shown, the Canadian-born children of South Asian immigrants are cast as symbols of tradition and modernity, and inhabit a liminal space between two seemingly irreconcilable cultures. Popular slang used across national contexts - the ABCD or American-born confused Desi, replaced by the 'coconut' in Canada and Britain typecast the diasporic experience of the "immigrant second generation" through conflicted racial identities and national loyalties. Sunaina Maira (2002) has argued that the anxieties and ambivalences of belonging by the immigrant first generation are transferred onto their children who then 'remix' culture in the quintessential position of diaspora, third space. While I turn to the ways in which the depictions of confusion and loss have been actively resisted by the second generation by placing new claims and demands on the national in the next section, opinions that stressed the failures of integration and of multicultural segregation were repeatedly expressed.

Rajiv expressed a hostility and antagonism among "South Asians". He contrasted his politics of belonging with what he described as his parents' "essentialist need" to associate with Indians. He noted that though his parents are not religious, they began religiously attending temple events to meet with friends. By contrast, in Rajiv's experience, association with other South Asians gave way to hostility as recognition served as a reminder of difference and the distance from incorporation.

"There is a common anti-brown thing that would happen. If I was walking down the street and I saw another South Asian guy across the road and I would be with my group of friends who would be predominantly Chinese, or white, and he would be with his friends. We would look at each other across the street as dogs look at each other". (personal interview with author).

The state or gaze that Rajiv described speaks to an antagonism that is borne out of the politics of incorporation.

The narratives above do not necessarily eschew a commitment to multiculturalism, but as Mary Thomas (2011) has shown in her analysis of interethnic and cross-racial interactions in a Los Angeles high school, they instead reflect a banal multiculturalism that touts a simplistic respect for the difference blocks meaningful engagement and working with difference. David Ley (2007: 14) has argued that discourses that critique multiculturalism are often the result of imputed meanings of multiculturalism, rather than recognition of its diverse practices and aims over almost forty years as Canadian national discourse. In particular, in the tenuous links made between segregation and multiculturalism, Ley contends, "multiculturalism is inflated to a size where it becomes the only target that is visible". The veracity of their claims regarding the levels of segregation in Canada is not the issue. With each repetition, such statements cannot be readily dismissed.

The creation and enforcement of geopolitical divisions block the formation of South Asian solidarities that have the potential to reimagine the contours of belonging within, across, and beyond the national. Long-distance nationalism, advanced by select diasporic subjects adhere to the scripts of national incorporation that foment new divisions in the diaspora. During interviews and conversations I conducted, desires to transform and alter the national instead more frequently expressed a desire for its preservation, and in which the role of the migrant and the diasporic is to act as national gatekeepers using their cultural capital and experiences gathered through their unique mobility and transnational ties. Their role was one of instructing the nation when its imaginings for inclusivity threaten to undermine the notion of community. The narratives above reflect an internalization of 
the exclusions of nationalism. The distinctions made by diasporic subjects in relation to national belonging and the norms of integration are an articulation of the fact that Whiteness provides the "point of departure for multiculture" (Bannerji 2000: 110). Immigrants are assessed in terms of their contributions and liabilities, always having to prove their worth to the nation (Dunn \& Mahtani 2001). The battle lines of multiculturalism are drawn around the immigrant neighbourhoods that in popular discourse separate national communities and the central national community from each other. Though the narratives above are filled with factual inaccuracies, and (trans-)nationalistic elitism, they reflect a geo-political discourse that revolves around the constructions of an ' $\mathrm{us}^{\prime}$ and 'them' in which immigrants position themselves against other immigrants in the name of incorporation. Such processes expose how the national interpellates migrants as national subjects.

\section{Replacing the nation with cross national solidarities}

In contrast to the attitudes expressed above, multiculturalism and national belonging were imagined in more productive, inclusive, and creative ways with other participants. Multiculturalism and the national remained a powerful idea in describing people's everyday lives and interactions in Toronto. Though Canada's national narrative, multiculturalism was taken down other paths and linked to other national histories and experiences that echo Yasmeen Abu-Laban's (2002) emphasis on the deessentialization of multiculturalism that neither fixes the nation or cultural identities. From this perspective, the national enables the interaction and engagement in new social and political movements and diasporic identities. In this section, I provide a tracing of South Asian solidarities and diasporic identities through the mundane interactions that take place in across city spaces consisting of business districts, school, and residential neighbourhoods. In these everyday encounters the dissonant utterances of national membership and belonging provide the terrains for new imaginaries that deploy the language of the national community, but in which the boundaries of national membership are transgressed and reconstituted. The very neighbourhoods and business districts, which are represented as the litmus tests for multicultur- alism, also reflect a diversity of the South Asian diaspora whose history and complex patterns of migration, settlement, and interaction have only recently become the subject of scholarly attention (Bald 2013). In the discussion on South Asian cross-national solidarities, I turn to practices in Toronto and New York City. By engaging with these two cities I suggest that transformations of the national and the formation of new diasporic identities have been occurring across national contexts.

Second generation South Asians have generated diasporic collectivities that stressed the multiple and shifting identities that moved across nations and thereby further pluralized the content of the national community (Das Gupta 1997). South Asian cultural and art festivals, such as Toronto's now defunct Desh Pardesh (Home Away from Home), New York's Diasporadics and transnational festivals such as Engendered, and regular Bollywood and Bhangra themed dance events overtly espouse a plural and heterogeneous understanding of community. These renderings simultaneously locate South Asians within the histories of migration and diversity in the United States and Canada as well as a critical placement of South Asia as a region and identity (Mani 2012). The expression of South Asian identities and solidarities found their initial articulations in the anti-racist work in the late-1970s. Today, these solidarities are expressed through organizations such as the Council of Agencies Serving South Asians, though relegating the cross-national emergence of diasporic identities to organizations obfuscates the everyday projects that transform the history of the nation. For instance, the resuscitation of histories of the 1914 journey of the Komagata Maru, the ship carrying over 300 passengers from India that was barred from docking at Vancouver's port, has become an important lineage for the contemporary relation between the South Asian diaspora and Canada, but as a means for creating new solidarities, as made clear in the website for the Brown Canada project.

\begin{abstract}
"As we reflect and remember, we must resist the urge to only look back in sorrow. Marginalized communities, including South Asian communities, have resisted and mobilized in astounding and inspiring ways. They did so in 1914, they continue to do so". (Brown Canada)
\end{abstract}

Such discourses and practices do not merely undo the national, but rather seek to illuminate the lineages of contemporary experiences of belong- 
ing, exclusion, and the occluded circuits of previous waves of transnational solidarities.

In the aftermath of 11 September, longstanding forms of immigrant, racial, and ethnic exclusion became the contours of nationalism in both the United States and Canada. For their prominent differences in nationalistic discourses that have been traditionally and popularly located in the distinctions between an official multicultural nationalism of Canada and an assimilationist United States, the parallels, both before and after-September $11^{\text {th }}$ were often in lockstep. South Asian immigrants became the targets of anti-immigrant discourse that became the grounds of national cohesion. Post9/11 exclusions in the United States and Canada were not unique. Indeed, its lineages could be found in the previous waves of anti-immigrant discourse and state policies that go back to the very founding of the United States, such as the Alien and Sedition Acts of 1798 that allowed for the deportation and imprisonment of aliens, to the "Hindu Menace" and Continuous Journey stipulation of the early $20^{\text {th }}$ centuries. Anti-Asian racism in both the United States and Canada led to the exclusion of Asian migrations through unique policies that employed the geographical mappings of race and national origins to exclude the migration of Asians that would not be reversed until the liberalization of immigration policies in both countries in the mid-1960s. The work of South Asian community activist groups in New York City, Chicago, Toronto, and other major population centres across North America placed their contemporary struggles and exclusions within the context of this until then marginalized history and as a result, transformed not only the imaginings of the nation, but shed light on the exclusionary policies of the state as well.

Furthermore, the aftermath of 11 September projected the securitized immigration regime that had become a cornerstone of American immigration policy particularly since Operation Gatekeeper in 1994 onto South Asians and Arabs. Post-9/11 nationalism most clearly highlighted the ease in which the violence that shifts immigrants from that of exalted status to a threatening outsider is predicated on an originary otherness in the first instance. As news of deportations, detention, and the special registration of non-immigrant visa holders from select countries swept across cities in the United States and Canada, new forms of political identity that negotiated the differences and diversity of South Asian identities emerged (Ashutosh 2008). Writing in the aftermath of September $11^{\text {th }}$, Jasbir
Puar and Amit Rai (2004: 87) searched for new ways of understanding transnational solidarities and social movements across racialized groups when they asked: "how do we make sense of these moments of a solidarity blocked or, better, a solidarity haunted, inhabited, exceeded by non-synthesizable singularities?". Embedded within this question is the importance of recognizing the contingencies of cross-class and cross-cultural solidarities that, as has been shown, have emerged in a transnational field and therefore, challenged national exclusions and essentialized notions of identity and community in both 'home' and 'host' societies.

Prior to September $11^{\text {th }}$, a number of organizations in both New York City and Toronto combated racism, gender and sexual violence, and immigrant exclusions through cross-national coalitions. In Toronto, the Association for South Asian Aids Prevention was formed in 1989 through the activities of the queer South Asian organization, Khush. A decade later, the South Asian Legal Clinic was established to provide legal services to low income South Asians in Toronto. Similar coalitions that adopted a diasporic optic of cross-national solidarities also emerged in New York, with The New York Taxi Workers Alliance that built a coalition across national, religious, racial, and linguistic divides that was powerfully expressed during the May 1998 strike initiated by taxi drivers against the severe measures initiated by the New York Taxi and Limousine Commission (Mathew 2005). South Asian labor, queer, and women organizations also drew their strength by negotiating national differences in what Monisha Das Gupta (2006) has termed "the transnational complex of rights" in which rights claims struggle with the exclusionary policies of the state and limits of membership of the nation. In Toronto, South Asian community organizing in the 1970s responded to racism that led to the development of anti-racist organizations that work alongside and with difference. Activist and researcher Uzma Shakir (2011: 185) called for open and broad conversations amongst Canada's diverse ethno-racial communities. It is the process of working and building new communities that Shakir described as "the most enlightening elements of my experience in Canada: building a sense of solidarity with people I might not have met or worked with otherwise. That is the most wonderful and unexpected benefit of being in Canada". In the creation of cross-national organizations, inclusive political solidarities challenge the national divides that dominated the narratives in the previous 
sections. These institutions disrupt the agonistic relations within South Asian communities and across ethnic and racial groups in which the nation and its constitutive elements of race and religion continue to provide the national as a site of division and exclusion, as discussed in the previous section.

The political actions and solidarities of the South Asian diasporas in the United States and Canada remain the most successful when they appeal to national membership and affiliation. It would be a mistake, however, to readily equate the placement of the national in immigrant politics and even independence day parades or cultural festivals as nationalist. As Sandhya Shukla has shown in her analysis of Indian festivals in London and New York City, nationalism "is not the primary consequence of complex forms of identification" (Shukla 2003: 13). Instead, these moments are the very grounds for a questioning, interrogation, and reconstitution of the national. For instance, protests led by the Sri Lankan Tamil community in Toronto against the civil war in Sri Lanka made claims for the national recognition of Tamil Eelam, but also grounded these claims through appeals to multiculturalism and the Canadian Charter of Rights and Freedoms. These protests, which included participation beyond that of one national group, also criticized the limits of contemporary national membership and state exclusions. The protests, moreover, attempted to disentangle national recognition and community from the violence of the state and are an instance in which new understandings and a re-signification of the national becomes possible.

\section{Conclusions}

The nation continues to play a vexed and contradictory role in shaping migrant processes, and immigrants occupy a paradoxical status in relation to the nation. As the objects of the nation, they ensure national unity and the grounds of belonging as a contrasting figure. Diasporic appeals to the nation are responsible for incorporations that raise increasingly insuperable barriers amongst migrants and racialized minorities and between select immigrants and natives. However, the national is transformed from within through political practices that seek to forge new collectives in which the national may be a transitory basis of community and interaction on the way towards a critical cross-national and cross-class solidarity. I focused on how national membership and belonging and its limits are lived and challenged by migrancy. The nation, therefore, divides as it incorporates, and the diverse practices that fall under its name reflect both a consonance and dissonance towards its narratives.

More broadly, the analysis provided here asks to what extent should scholarship invest in the national as an analytic for understanding, and indeed re-inscribing, difference? The precise way in which the nation is reimagined remains an open question. It, of course, involves political action. However, it also depends on the development of epistemologies that hinge on a multi-scalar approach to the national. How the global, national, and local are imbricated in the constitution of subjects, and how do these subjects, in turn, make and remake these structures? What is certain, however, is that globalization discourses that once proclaimed the end of the nation-state were premature. The rise of transnational capital and the new international division of labour that structures global migrations have not led to the wholesale withering away from the nation-state. Similar to the analyses on the rescaling of the state (Brenner 2004), I have, in this paper, called for a reenergized focus on the rescaling and diverse uses of the nation through grounded, empirical work in cities. This renewed emphasis on the national avoids the methodological nationalism by focusing instead on the slippage of categories produced in the ever-shifting grounds of the nation's people. Rather than placing the relation between the national belonging/global migrations as a categorical proposition, this paper has engaged with the myriad of ways in which the nation is reproduced and engenders overlapping forms of belonging.

\section{REFERENCES}

Abu-Laban Y 2002. Liberalism, multiculturalism and the problem of essentialism 1. Citizenship Studies 6: 4, 459-482.

http://dx.doi.org/10.1080/1362102022000041268.

Anderson B 1991. Imagined communities. Verso, London.

Anderson B 1992. Long-distance nationalism. Centre for Asian Studies, Amsterdam.

Anderson K 1995. Vancouver's Chinatown: racial discourse in Canada, 1875-1980. McGill-Queens, Montreal and Kingston.

Appadurai A 1996. Modernity at large: the cultural dimensions of globalization. University of Minnesota Press, Minneapolis. 
Ashutosh I 2008. (Re-)Creating the community: South Asian transnationalism on Chicago's Devon Avenue. Urban Geography 29: 3, 224-245.

http://dx.doi.org/10.2747/0272-3638.29.3.224.

Ashutosh I 2014. From the census to the city: representing South Asians in Canada and Toronto. Diaspora 17: 2, 130-148.

http://dx.doi.org/10.1353/dsp.2014.0001.

Axel BK 2001. The nation's tortured body. Duke University Press, Raleigh and Durham.

BaldV 2013. Bengali Harlem and the lost histories of South Asia America. Harvard University Press, Cambridge.

Balibar E 2004. We, the people of Europe: reflections on transnational citizenship. Princeton University, Princeton and Oxford.

Bannerji H 2000. Dark side of the nation: essays on multiculturalism, nationalism and gender. Scholars Press, Toronto.

Barber J \& Bonoguore T 2007. Where do we go from here? Globe and Mail, 8 December, p. M1.

Basch L, Schiller NG \& Blanc CS 1994. Nations unbound: transnational projects, postcolonial predicaments, and deterritorialized nation-states. Gordon and Breach Science Publishers, Amsterdam.

Baumann G 1996. Contesting culture: discourses of identity in multi-ethnic London. Cambridge University Press, Cambridge.

Bhabha H 1994. The location of culture. Routledge, New York.

Bhachu P 1985. Twice migrants: East African Sikh settlers in Britain. Tavistock, London.

Brenner N 2004. New state spaces. Oxford University Press, New York.

Brown Canada. Komagata Maru. <http://km.browncanada.com/komagatamaru.php> 15.10.2014.

Buchignani N 1980. Accommodation, adaptation, and policy: dimensions of the South Asian experience in Canada. In Ujimoto KV \& Hirabayashi G (eds). Visible minorities and multiculturalism: Asians in Canada, 121-150. Butterworths,Scarborough, ON.

Butler J \& Spivak S 2007. Who sings the nationstate? Language, politics, belonging. Seagull Books, Oxford.

Carter S 2005. Geopolitics of diaspora. Area 37: 1, 54-63. http://dx.doi.org/10.1111/j.1475-4762.2005.00601.x.

Clifford J 1994. Diasporas. Cultural Anthropology 9: 3, 302-338.

http://dx.doi.org/10.1525/can.1994.9.3.02a00040.

Cohen R 1997. Global diasporas. Routledge, London.

Das Gupta M 1997. 'What is Indian about you?' A gendered, transnational approach to ethnicity. Gender and Society 11: 5, 576-596. http://doi.org/10.1177/089124397011005004.

Das Gupta M 2006. Unruly immigrants. Duke University Press, Durham.

Dickinson J \& Bailey A 2007. Remembering diaspora: uneven geographies of citizenship. Political Geography 26: 7, 757-774.

http://dx.doi.org/10.1016/j.polgeo.2007.03.007.

Dunn K \& Mahtani M 2001. "Adjusting the color bars": media representations of ethnic minorities under Australian and Canadian multiculturalisms. Working paper series 01-06. Research on Immigration and Integration in the Metropolis, the Vancouver Centre.

Duara P 1995. Rescuing history from the nation. University of Chicago Press, Chicago.

Dwyer C 2002. Where are you from? Young British Muslim women and the making of 'home.' In Blunt A \& McEwan C (eds). Postcolonial geographies, 184-199. Continuum, New York.

Edensor T 2002. National identity, popular culture and everyday life. Berg, Oxford.

Ellis M \& Wright R 1998. The balkanization metaphor in the analysis of US immigration. Annals of the Association of American Geographers 88: 4, 686698. http://dx.doi.org/10.1111/0004-5608.00118.

Fong E 2006. Residential segregation of visible minority groups in Toronto. In Fong E (ed). Inside the mosaic, 51-75. University of Toronto Press, Toronto.

Fuglerud O 1999. Life on the outside: the Tamil diaspora and long-distance nationalism. Pluto Press, London.

Ghosh S 2013. 'Am I South Asian, really?' Constructing South Asianness in Canada and being South Asian in Toronto." South Asian Diaspora 5:1, 35-55. http://dx.doi.org/10.1080/19438192.2013.724913.

Gilroy P 1993. The Black Atlantic: modernity and double consciousness. Harvard University Press, Cambridge.

Grewal I 2005. Transnational America. Duke University Press, Durham.

Haque E 2010. Homegrown, Muslim and other: tolerance, secularism and the limits of multiculturalism. Social Identities: Journal for the Study of Race, Nation and Culture 16:1, 79-101. http://dx.doi.org/10.1080/13504630903465902.

Handa A 2003. Of silk saris and mini skirts: South Asian girls walk the tightrope of culture. Women's Press, Toronto.

Harris C 2001. Postmodern patriotism: Canadian reflections. The Canadian Geographer / Le Géographe canadien 45: 2, 193-207.

http://dx.doi.org/10.1111/j.1541-0064.2001.tb01185.x.

Hiebert D 2005. Migration and the demographic transformation of Canadian cities: the social geography of Canada's major metropolitan centres in 2017. Working paper series 05-14. Research on Immigration and Integration in the Metropolis, the Vancouver Centre.

Honig B 2001. Democracy and the foreigner. Princeton University Press, Princeton.

Human Rights Watch 2006. Funding the "Final War": LTTE intimidation and extortion in the Tamil diaspora. HRW report 18 (1). Human Rights Watch, New York and London.

Jimenez M 2007. Do ethnic enclaves impede integration? Globe and Mail, 8 February, p. A8.

Joppke C 2004. The retreat of multiculturalism in the liberal state: theory and policy. The British Journal of Sociology 55: 2, 237-257.

http://dx.doi.org/10.1111/j.1468-4446.2004.00017.x. 
Kymlicka W 1995. Multicultural citizenship. Clarendon Press, Oxford.

Ley D 2007. Multiculturalism: a Canadian defence. Working paper series 07-04. Research on Immigration and Integration in the Metropolis, the Vancouver Centre.

Ley D 2010. Millionaire migrants: trans-Pacific life lines. Wiley, Malden.

Ley D \& Smith HA 1997. Immigration and poverty in Canadian cities, 1971-1991. Canadian Journal of Regional Science 20: 1-2, 29-48. http://dx.doi.org/10.1080/0042098002285.

Li P 2003. Deconstructing Canada's discourse of immigrant integration. Journal of International Migration and Integration / Revue de l'integration et de la migration international 4: 3, 315-333. http://dx.doi.org/10.1007/s12134-003-1024-0.

Li W 2009. Ethnoburb: the new ethnic community in urban America. University of Hawaii Press, Honolulu.

Maharaj B 2003. Comparative reflections on the Indian diaspora: historical and recent perspectives. In Varma S \& Seshan R (eds). Fractured identity: the Indian diaspora in Canada, 48-65. Rawat, Jaipur.

Mahler S 1995. American dreaming: immigrant life on the margins. Princeton University Press, Princeton.

Maira S 2002. Desis in the house: Indian American youth culture in New York City. Temple University Press, Philadelphia.

Mani B 2012. Aspiring to home: South Asians in America. Stanford University Press, Stanford.

Mathew B 2005. Taxi. The New Press, New York.

Miller J \& Sack C 2010. The Toronto - 18 terror case; trial by media? How newspaper opinion framed Canada's biggest terrorism case. The International Journal of Diversity in Organisations, Communities and Nations 10: 1, 279-296.

Mitchell K 1997. Different diasporas and the hype of hybridity. Environment and Planning D: Society and Space 15: 5, 533-53. http://dx.doi.org/10.1068/d150533.

Mitchell T 1988. Colonizing Egypt. University of California Press, Berkeley and Los Angeles.

Murdie RA 2008. Diversity and concentration in Canadian immigration: trends in Toronto, Montréal and Vancouver, 1971-2006. Research Bulletin 42. Centre for Urban and Community Studies (Cities Centre), Toronto.

Myles J \& Hou F 2004. Changing colours: spatial assimilation and new racial minority immigrants. The Canadian Journal of Sociology 29: 1, 29-58. http://dx.doi.org/10.1353/cjs.2004.0011.

Nairn T 1975. The modern janus. New Left Review I/94, 3-29.

Ong A 1999. Flexible citizenship: the cultural logics of transnationality. Duke University Press, Durham and London.

Prashad V 2000. The karma of brown folk. University of Minnesota Press, Minneapolis, MN.

Preston V \& Lo L 2000. "Asian theme malls in suburban Toronto: land use conflict in Richmond Hill." The Canadian Geographer 44: 2, 86-94. http://dx.doi.org/10.1111/j.1541-0064.2000.tb00701.x.

Puar J \& Rai A 2004. The remaking of a model minority: perverse projectiles under the specter of (counter)terrorism. Social Text 22: 3_80, 75-104. http://dx.doi.org/10.1215/01642472-22-3_80-75.

Qadeer M 2003. Ethnic segregation in a multicultural city: the case of Toronto, Canada. Working paper 28. Joint Centre of Excellence for Research on Immigration and Settlement, Toronto.

Qadeer M, Agrawal SK \& Lovell A 2010. Evolution of ethnic enclaves in the metropolitan Toronto area, 2001-2006. International Migration and Integration 11: 3, 315-339. http://dx.doi.org/10.1007/s12134-010-0142-8.

Razack S 2007. The 'Sharia law debate' in Ontario: the modernity/premodernity distinction in legal efforts to protect women from culture. Feminist Legal Studies 15: 1, 3-32. http://dx.doi.org/10.1007/s10691-006-9050-x.

Rouse R 1991. Mexican migration and the social space of postmodernism. Diaspora 1: 1, 8-23. http://dx.doi.org/10.1353/dsp.1991.0011.

Rudrappa S 2004. Ethnic routes to becoming American: Indian immigrants and the culture of citizenship. Rutgers University Press, New Brunswick.

Rushdie S 1991. Imaginary homelands: essays and criticism 1981-1991. Penguin Books, London.

Sassen S 1996. Losing control? Sovereignty in an age of globalization. Columbia University Press, New York.

Shakir U 2011. The colour of poverty. In Chazan M, Helps L, Stanley A \& Thakkar S (eds). Home and native land, 184-191. Between the Lines, Toronto.

Schiller NG \& Fouron G 2001. Georges woke up laughing: long-distance nationalism and the search for home. Duke University Press, Raleigh.

Shukla S 2003. India abroad. Princeton University Press, Princeton.

Siemiatycki M 2012. "Toronto: integration in a city of immigrants." In Andrew C, Biles J, Burstein $\mathrm{M}$, Esses V \& Tolley $\mathrm{E}$ (eds). Immigration, integration, and inclusion in Ontario cities, 23-48. McGill-Queen's University Press, Montréal and Kingston.

Soysal YN 1994. Limits of citizenship. University of Chicago Press, Chicago.

Statistics Canada 2011. Immigration and ethnocultural diversity in Canada. <http://www12.statcan.gc.ca/nhs-enm/2011/as-sa/99-010-x/99-010x2011001-eng.cfm> 15.10.2014.

Taylor C 1994. The politics of recognition. In Gutmann A (ed). Multiculturalism and the 'politics of recognition', 25-73. Princeton University Press, Princeton.

Teelucksingh C 2006. Toward claiming space. In Teelucksingh C (ed). Claiming space, 1-17. Wilfrid Laurier Press, Waterloo.

Thobani S 2007. Exalted subjects: studies in the making of race and nation in Canada. University of Toronto Press, Toronto.

Thomas M 2011. Multicultural girlhood. Temple University Press, Philadelphia. 
Tololyan K 1991. The nation-state and its others. Diaspora 1: 1, 3-7. http://dx.doi.org/10.1353/dsp.1991.0008

Toronto Star 1992. 'Toronto has become an exciting, cosmopolitan city, thanks in part to the influx of people from many lands. Much of this tide of human gold has flowed from the world's biggest continent ... ASIA'. Toronto Star, The (Ontario, Canada), 15.10.2014, p. E1.

Ubale B 1992. Politics of exclusion. Ampri Press, North York.

Van der Veer P 1995. The diasporic imagination. In van der Veer $\mathrm{P}$ (ed). Nation and migration, 1-16. University of Pennsylvania Press, Philadelphia.

Varadarajan L 2010. The domestic abroad: diasporas in international relations. Oxford University Press, Oxford.

Vertovec S \& Wessendorf S 2010. Introduction: assessing the backlash against multiculturalism in Europe. In Vertovec S \& Wessendorf S (eds). The multicultural backlash, 1-31. Routledge, New York.
Walton-Roberts M 2011. Immigration, trade and 'ethnic surplus value': a critique of Indo-Canadian transnational networks. Global Networks 11: 2, 203-221. http://dx.doi.org/10.1111/j.1471-0374.2011.00318.x.

Walton-Roberts M \& Pratt G 2005. Mobile modernities: a South Asian family negotiates immigration, gender and class in Canada. Gender, Place and Culture 12: 2, 173-195.

http://dx.doi.org/10.1080/09663690500094823.

White MJ, Fong E \& Cai Q 2003. The segregation of Asian-origin groups in the United States and Canada. Social Science Research 32: 148-167. http://dx.doi.org/10.1016/s0049-089x(02)00023-6.

Wimmer A \& Glick-Schiller N 2002. Methodological nationalism and beyond: nation-state building, migration and the social sciences. Global Networks 2: 4, 301-334.

http://dx.doi.org/10.1111/1471-0374.00043. 